\title{
Analiza sygnałów wibroakustycznych w procesie monitorowania stanu zawieszenia pojazdów szynowych oraz toru
}

\begin{abstract}
Przedmiotem artykułu jest analiza wyników pomiarów przyspieszeń na wybranych elementach pojazdu szynowego, na którym zostat zainstalowany prototyp Systemu monitorowania stanu i diagnozowania po-jazdów szynowych oraz toru. Pośród tych elementów wyróżnia się: obudowy tożysk maźniczych, ramy wózków i nadwozia wagonów lub członów pojazdu szynowego. Analizy dokonano na przykładzie wybranego fragmentu krajowej sieci kolejowej - rozpatrzeniu poddano przejazdy pojazdu szynowego wzdtuż określonego odcinka linii kolejowej numer 3. Wyniki pomiarów zostaty odpowiednio przeksztatcone tj. przeliczone do wartości określonych wskaźników diagnostycznych. Wartości wskaźników diagnostycznych, po porównaniu z wartościami dopuszczalnymi (określonymi dla każdego typu wskaźników przy uwzględnieniu lokalizacji miejsc pomiarowych), pozwalaja na monitorowanie typowych dynamicznych zachowań pojazdu szynowego i stanu toru oraz temperatury maźnic zestawów kołowych pojazdu szynowego oraz na określenie stanu technicznego konstrukcji rozpatrywanego pojazdu szynowego. Celem analiz jest określenie użyteczności poszczególnych wskaźników diagnostycznych przy jednoczesnym wskazaniu dalszych kierunków badań nad systemem.
\end{abstract}

\section{Wprowadzenie}

W ramach projektu badawczego MONIT - ,Monitorowanie Stanu Technicznego Konstrukcji i Ocena jej Żywotności" - realizowanego w ramach Programu Operacyjnego Innowacyjna Gospodarka (PO IG) Poddziatanie 1.1.2 Strategiczne programy badań naukowych i prac rozwojowych opracowywane sa systemy i rozwiązania znajdujące zastosowanie m.in. w: lotnictwie, energetyce, przemyśle chemicznym oraz przy monitorowaniu stanu technicznego konstrukcji budowlanych czy wreszcie w transporcie. Jednym z przygotowywanych rozwiązań jest Systemu monitorowania stanu $i$ diagnozowania pojazdów szynowych oraz toru. Zadaniem systemu jest monitorowanie typowych dynamicznych zachowań pojazdu szynowego i stanu toru oraz temperatury maźnic zestawów kołowych pojazdu szynowego. Wobec prawidłowego funkcjonowania systemu na etapie jego eksploatacji nadzorowanej analizowane są dane uzyskane w wyniku pomiarów w trakcie przejazdów pojazdu szynowego, na którym zainstalowano prototyp systemu.

Przedmiotem artykułu jest analiza wyników pomiarów przyspieszeń na maźnicach, ramach wózków i nadwoziach (pudłach) wagonów lub członów pojazdu szynowego. Analizy dokonano na przykładzie wybranego fragmentu krajowej sieci kolejowej.
System monitorowania stanu i diagnozowania pojazdów szynowych oraz toru umożliwia monitorowanie stanu pojazdu poprzez akwizycję i wstępną analizę danych drganiowych oraz procesowych. Zmierzone dane poddawane są obróbce cyfrowej oraz walidacji. W przypadku wykrycia nieprawidłowości informacja o niej przesyłana jest na zewnętrzny serwer w postaci pakietu kontrolnego za pośrednictwem modemu $G S M$. Również dane uzyskane w wyniku pomiarów mogą być wysyłane na serwer w postaci pakietu danych.

Monitorowanie stanu pojazdów szynowych jest prowadzone on-line (na bieżąco), a zbierane przez czujniki sygnały są na bieżąco analizowane i gromadzone w bazach danych serwera systemu.

Opracowana została struktura funkcjonalna systemu (rys. 1.). Sygnały z czujników są przesyłane drogą przewodową do lokalnej jednostki akwizycji danych zamontowanej na pojeździe. Następnie sygnały są przesyłane (także drogą przewodowa) do centralnej jednostki akwizycji danych, gdzie podlegają wstępnej analizie. W dalszej kolejności sygnały $\mathrm{z}$ centralnej jednostki akwizycji danych przesyłane są drogą bezprzewodową do serwera systemu gdzie podlegają szerszej analizie i są gromadzone w bazie danych. W wyniku analizy obliczane są odpowiednie. 
wskaźniki diagnostyczne (amplituda, wartość średniokwadratowa, współczynnik kurtozy, rozstęp międzykwartylowy, jakość toru) charakteryzujące stan techniczny, a następnie generowane są informacje jakościowe o stanie technicznym. Informacje te są na bieżąco przesyłane do odpowiednich służb nadzorujących ruch pojazdu oraz służb odpowiedzialnych za stan techniczno-eksploatacyjny pojazdu i toru. Ruch pojazdu jest opisany współrzędnymi geograficznymi i jest widoczny na elektronicznej mapie Polski, zatem informacje o pojeździe i stanie toru są jednoznacznie identyfikowane $\mathrm{z}$ miejscem $\mathrm{w}$ terenie. W związku z tym operator pojazdu otrzymuje informacje o zachowaniu się pojazdu na odpowiednim szlaku.

Gromadzone w bazie danych informacje są wykorzystywane do oceny stanu technicznego elementów podatnych i thumiących I i II stopnia sprężynowania pojazdu oraz do oceny stanu toru. Bazując na tych informacjach możliwe jest podejmowanie decyzji o koniecznych naprawach, remontach czy wymianach elementów pojazdu

System monitorowania stanu i diagnozowania pojazdów szynowych oraz toru składa się z następujących podsystemów (rys 1.):

- podsystemu pokładowego,

- podsystemu użytkownika,

- podsystemu serwera przetwarzania danych,

Podsystem pokładowy ma budowę modułowa. Składa się z modułu centralnej jednostki akwizycji danych oraz pewnej liczby modułów lokalnych jednostek akwizycji danych zależnej od liczby członów wchodzących w skład pojazdu szynowego.

Podsystem pokładowy składa się z następujących komponentów:

- centralna jednostka akwizycji danych,

- lokalne jednostki akwizycji danych (podzespół predefiniowany na potrzeby systemu),

- czujniki przyspieszeń

- czujniki temperatury,

- oprogramowanie.

Centralna jednostka akwizycji danych $(C J A D)$ to komputer przemysłowy używany w kolejnictwie, zgodny ze standardem EN50155.

Centralna jednostka akwizycji danych znajduje się w jednym ze skrajnych członów pojazdu szynowego. Jedna centralna jednostka akwizycji danych przypada na jeden pojazd szynowy.

Rolą jej jest zbieranie sygnałów z lokalnych jednostek akwizycji danych, przeprowadzanie analiz w oparciu o te sygnały oraz przesyłanie pakietów danych i pakietów kontrolnych do podsystemu serwera przetwarzania danych.

Komunikacja między centralną jednostką akwizycji danych a lokalnymi jednostkami akwizycji danych odbywa się drogą kablową za pośrednictwem sieci typu Ethernet.
Komunikacja między centralną jednostką akwizycji danych a podsystemu serwera przetwarzania danych odbywa się bezprzewodowo, za pośrednictwem systemu telekomunikacji GSM.

Lokalne jednostki akwizycji danych (LJAD) zabudowane są w szczelnych obudowach. Jedna lokalna jednostka akwizycji danych przypada na jeden człon pojazdu szynowego.

Rolą lokalnych jednostek akwizycji danych jest zbieranie, kondycjonowanie i koordynacja sygnałów pochodzących z czujników, a także przesyłanie sygnałów do centralnej jednostki akwizycji danych.

Komunikacja między centralną jednostką akwizycji danych a lokalnymi jednostkami akwizycji danych odbywa się drogą kablową za pośrednictwem sieci typu Ethernet. Natomiast komunikacja między lokalnymi jednostkami akwizycji danych a czujnikami odbywa się drogą przewodową.

$\mathrm{Na}$ rys. 2. przedstawiono schemat elektrycznego zespołu trakcyjnego ED74, tj. pojazdu, na którym został zainstalowany prototyp systemu, wraz z uwzględnieniem symbolicznych oznaczeń wózków pojazdu szynowego oraz przyporządkowaniem im lokalnych jednostek akwizycji danych $(L J A D)$ stanowiących część składową Systemu monitorowania stanu $i$ diagnozowania pojazdów szynowych oraz toru. Gromadzenie i przesył danych do centralnej jednostki akwizycji danych $(C J A D)$ w przypadku wózka napędowego oznaczonego symbolem $A$ jest realizowane przez LJAD5; w przypadku wózka tocznego oznaczonego symbolem $B$ jest realizowane przez LJAD4; w przypadku wózka tocznego oznaczonego symbolem $C$ jest realizowane przez LJAD3; w przypadku wózka tocznego oznaczonego symbolem $D$ jest realizowane przez LJAD2; w przypadku wózka napędowego oznaczonego symbolem $E$ jest realizowane przez LJAD1.

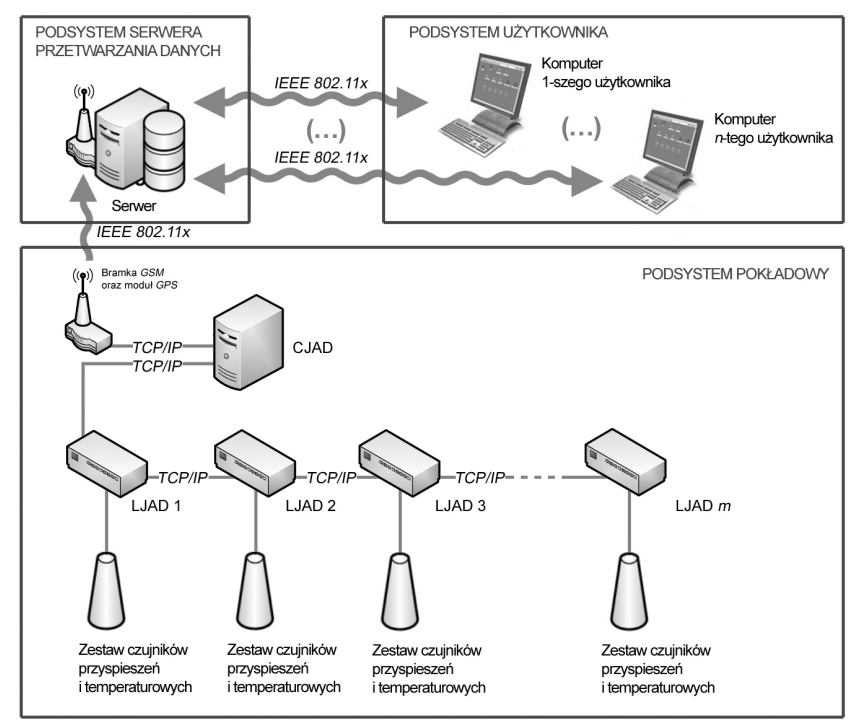

Rys. 1. Schemat system monitorowania stanu i diagnozowania pojazdów szynowych oraz toru Źródło: opracowanie własne 


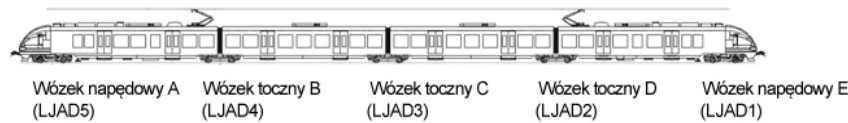

Rys. 2. Schemat elektrycznego zespołu trakcyjnego ED74 0001 wraz z uwzględnieniem symbolicznych oznaczeń wózków pojazdu szynowego oraz przyporządkowaniem im lokalnych jednostek akwizycji danych (LJAD) Źródło: opracowanie własne na podstawie $[8,9]$

Wybraną dla przeprowadzenia analiz pomiarów jest trasa stanowiąca część składową linii kolejowej nr 3, łączącej Warszawę Zachodnią z Frankfurtem nad Odrą. Linia kolejowa nr 3 stanowi jednocześnie fragment międzynarodowej linii kolejowej E20. Dokładniej rzecz ujmując rozpatrywana trasa to linia kolejowa pomiędzy Warszawą a Poznaniem (wyłącznie w relacji Warszawa-Poznań). Pojazd szynowy na tej trasie przemieszczał się $\mathrm{w}$ następujących dniach (przy uwzględnieniu pomiarów do dnia 7 lutego 2012 r.): 18,19 listopada 2011 r., 23, 25, 26 stycznia $2012 \mathrm{r}$.

W poszczególnych dniach zarejestrowane zostały następujące liczby pakietów:

- 18 listopada 2011 r.: wózek $A$ : 97 pakietów, wózek $B$ : 97 pakietów, wózek $C$ : 27 pakietów, wózek $D$ : 96 pakietów, wózek $E$ : 97 pakietów,

- 19 listopada 2011 r.: wózek $A$ : 107 pakietów, wózek $B: 108$ pakietów, wózek $C$ : 108 pakietów, wózek $D: 108$ pakietów, wózek $E: 105$ pakietów,

- 23 stycznia 2012 r.: wózek $A$ : 15 pakietów, wózek $B: 12$ pakietów, wózek $C: 34$ pakiety, wózek $D: 45$ pakietów, wózek $E$ : 46 pakietów,

- 25 stycznia 2012 r.: wózek $A$ : 0 pakietów, wózki $B, C, D, E$ : po 88 pakietów,

- 26 stycznia 2012 r.: wózek $A$ : 16 pakietów, wózek $B$ : 47 pakietów, wózek $C$ : 46 pakietów, wózek $D: 47$ pakietów, wózek $E$ : 43 pakiety.

$\mathrm{W}$ artykule każdorazowo, gdy mowa jest o przekroczeniach wartości dopuszczalnych dotyczących wskaźników diagnostycznych, odnosi się to do wartości wskazanych w tabeli 1.

\section{Analiza wybranych parametrów statystycznych}

W artykule analizie poddane są dwa wskaźniki diagnostyczne: Amplituda, Wartość średniokwadratowa. Pozostałe wskaźniki diagnostyczne nie są analizowane $\mathrm{z}$ uwagi na fakt, że trwają prace nad warto- ściami dopuszczalnymi ich dotyczącymi. Dodatkowemu omówieniu podlega Wspótczynnik kurtozy.

\section{Amplituda}

Zgodnie $\mathrm{z}$ zaleceniami zawartymi $\mathrm{w}$ karcie UIC518 amplitudę sygnału rozpatruje się poprzez pryzmat jej percentyla $99,85 \%$.

$\mathrm{Z}$ uwagi na nierównomierny rozkład liczb przesyłanych pakietów nie można jednoznacznie stwierdzić, w przypadku którego wózka występowało najwięcej przekroczeń wartości wskaźników diagnostycznych. Można jedynie wskazać procentowy udział liczby pakietów zawierających przekroczenia wobec łącznej liczby pakietów rozpatrzonych przez oprogramowanie analizujące przypadającej na poszczególne wózki pojazdu szynowego. W przypadku analizowania dopuszczalnych poziomów Amplitudy wyniki zawarto w tabeli 2. (wartości uznane za najwyższe pogrubiono). W ujęciu procentowym, w przypadku rozpatrywanych wskaźników diagnostycznych, do przekroczenia ich dopuszczalnych wartości najczęściej dochodzi w przypadku wózków o skrajnym położeniu tj. wózków napędowych $A$ i $E$ oraz w przypadku wózka $D$. Z kolei najwięcej, w ujęciu bezwzględnym, przekroczeń dotyczy wózków $E$ oraz $D$ (tabela 2.) oraz nadwozi pojazdu szynowego $A$ i $B / A$ (tabela 2.) w przypadku Amplitudy.

Z uwagi na duże liczby zarejestrowanych przekroczeń w przypadku parametru statystycznego Amplituda utrudnione jest przedstawienie przykładu zestawienia pakietów zawierających przekroczenia. Na przykład w dniu 26 stycznia 2012 r., na wózku $A$, nastapiło zarejestrowanie przez odpowiednie czujniki 190 przekroczeń „skupionych” w 7 pakietach, [10]. Jak wykazały analizy, do największych przekroczeń doszło w miejscach rozjazdów kolejowych w okolicy dworca kolejowego Poznań Wschód, [10]. Ze względu na liczbę przekroczeń nie jest możliwe przytoczenie identyfikacji miejsc ich wystapienia w artykule.

Amplituda ze względu na silną podatność na zmiany w badanym układzie (pojazd szynowym-tor) nie jest skutecznym wyznacznikiem przy monitorowaniu pojazdu prowadzącym do jego diagnozowania. Przejawem tego jest zdecydowanie rozbieżne procentowe porównanie liczby pakietów z przekroczeniami przypadającej na łacznq liczbę pakietów w przypadku każdego z rozpatrywanych wózków pojazdu szynowego (tabela 2.).

Wartości dopuszczalne rozpatrywanych wskaźników diagnostycznych Tabela 1.

\begin{tabular}{|c|c|c|c|c|c|c|}
\hline $\begin{array}{c}\text { Lokalizacja punktu } \\
\text { pomiarowego }\end{array}$ & Kierunek & $\begin{array}{c}\text { Amplituda } \\
{\left[\mathrm{m} / \mathrm{s}^{2}\right]}\end{array}$ & $\begin{array}{l}\text { Wartość średnio- } \\
\text { kwadratowa }\left[\mathrm{m} / \mathrm{s}^{2}\right]\end{array}$ & $\begin{array}{c}\text { Współczynnik } \\
\text { kurtozy }\end{array}$ & $\begin{array}{c}\text { Rozstęp między- } \\
\text { kwartylowy }\end{array}$ & $\begin{array}{l}\text { Stan } \\
\text { toru }\end{array}$ \\
\hline \multirow[t]{2}{*}{ Nadwozie } & poprzeczny & 2,5 & 0,5 & \multirow{6}{*}{\multicolumn{3}{|c|}{ W fazie opracowywania }} \\
\hline & pionowy & 2,5 & 0,75 & & & \\
\hline \multirow[t]{2}{*}{ Rama wózka } & poprzeczny & 10,9 & 5 & & & \\
\hline & pionowy & 20 & 7 & & & \\
\hline \multirow[t]{2}{*}{ Obudowa maźnicy } & poprzeczny & 18 & - & & & \\
\hline & pionowy & 76 & - & & & \\
\hline
\end{tabular}


Tabela 2.

Analiza przekroczeń dopuszczalnych poziomów Amplitudy wg czujników pomiarowych o wskazanych położeniach na wózkach i nadwoziach pojazdu szynowego (* E-Ø; ** E-czujnik 6, pionowy kierunek pomiaru)

\begin{tabular}{|c|c|c|c|c|c|c|}
\hline \multicolumn{2}{|c|}{ Oznaczenie wózka } & $A$ & $B$ & $C$ & $D$ & $E$ \\
\hline \multirow{5}{*}{$\begin{array}{l}\text { Liczba pakietów z prze- } \\
\text { kroczeniami/ Lączna } \\
\text { liczba pakietów }\end{array}$} & 18.11.11 & 29/97 (30\%) & $32 / 97(33 \%)$ & $1 / 27(4 \%)$ & $33 / 96(34 \%)$ & $21 / 97(22 \%)$ \\
\hline & 19.11.11 & $54 / 107(50 \%)$ & $35 / 108(32 \%)$ & $32 / 108(30 \%)$ & $39 / 108(36 \%)$ & $37 / 105(35 \%)$ \\
\hline & 23.01 .12 & $5 / 15(33 \%)$ & $3 / 12(25 \%)$ & $16 / 34(47 \%)$ & $17 / 45(38 \%)$ & $29 / 46(63 \%)$ \\
\hline & 25.01 .12 & - & $25 / 88(28 \%)$ & $27 / 88(31 \%)$ & $29 / 88(33 \%)$ & $24 / 88(27 \%)$ \\
\hline & 26.01 .12 & $7 / 16(44 \%)$ & $24 / 47(51 \%)$ & $23 / 46(50 \%)$ & $18 / 47(38 \%)$ & $29 / 43(67 \%)$ \\
\hline \multicolumn{2}{|c|}{ Czujnik 1, kierunek poprzeczny* 1} & 76 & 278 & 219 & 807 & - \\
\hline \multicolumn{2}{|c|}{ Czujnik 2, kierunek poprzeczny* } & 0 & 477 & 252 & 665 & - \\
\hline \multicolumn{2}{|c|}{ Czujnik 3, kierunek pionowy } & 888 & 1368 & 1090 & 1920 & 2568 \\
\hline \multicolumn{2}{|c|}{ Czujnik 4, kierunek pionowy** } & 1137 & 1378 & 1508 & 462 & 1860 \\
\hline \multicolumn{2}{|c|}{ Oznaczenia nadwozia } & $A$ & $B / A$ & $C / B$ & $D / C$ & D \\
\hline \multicolumn{2}{|c|}{ Czujnik 5, kierunek pionowy } & 276 & 220 & 117 & 234 & 98 \\
\hline \multicolumn{2}{|c|}{ Czujnik 6, kierunek poprzeczny* } & 84 & 154 & 3 & 87 & - \\
\hline
\end{tabular}

Źródło: opracowanie własne na podstawie [10]

Tabela 3.

Analiza przekroczeń dopuszczalnych poziomów Wartość średniokwadratowa wg czujników pomiarowych o wskazanych położeniach na wózkach i nadwoziach pojazdu szynowego (* E-Ø; ** E-czujnik 6, pionowy kierunek pomiaru)

\begin{tabular}{|l|c|c|c|c|c|c|}
\hline \multicolumn{1}{|c|}{ Oznaczenie wózka } & $\boldsymbol{A}$ & $\boldsymbol{B}$ & $\boldsymbol{C}$ & $\boldsymbol{D}$ & $\boldsymbol{E}$ \\
\hline \multirow{3}{*}{$\begin{array}{l}\text { Liczba pakietów z prze- } \\
\text { kroczeniami/ Lączna } \\
\text { liczba pakietów }\end{array}$} & $\mathbf{1 8 . 1 1 . 1 1}$ & $17 / 97(\mathbf{1 7 \%})$ & $14 / 97(14 \%)$ & $3 / 27(11 \%)$ & $0 / 96(0 \%)$ & $0 / 97(0 \%)$ \\
\cline { 2 - 7 } & $\mathbf{1 9 . 1 1 . 1 1}$ & $19 / 107(\mathbf{1 9 \%})$ & $3 / 108(3 \%)$ & $2 / 108(2 \%)$ & $6 / 108(6 \%)$ & $8 / 105(8 \%)$ \\
\cline { 2 - 7 } & $\mathbf{2 3 . 0 1 . 1 2}$ & $0 / 15(0 \%)$ & $0 / 12(0 \%)$ & $1 / 34(1 \%)$ & $2 / 45(1 \%)$ & $1 / 46(1 \%)$ \\
\cline { 2 - 7 } & $\mathbf{2 5 . 0 1 . 1 2}$ & - & $0 / 88(0 \%)$ & $0 / 88(0 \%)$ & $1 / 88(1 \%)$ & $0 / 88(0 \%)$ \\
\cline { 2 - 7 } & $\mathbf{2 6 . 0 1 . 1 2}$ & $0 / 16(0 \%)$ & $0 / 47(0 \%)$ & $0 / 46(0 \%)$ & $0 / 47(0 \%)$ & $0 / 43(0 \%)$ \\
\hline Czujnik 1, kierunek poprzeczny* & 0 & 0 & 0 & 0 & - \\
\hline Czujnik 2, kierunek poprzeczny* & 0 & 0 & 0 & $\mathbf{1}$ & - \\
\hline Czujnik 3, kierunek pionowy & 5 & 1 & 4 & 3 & $\mathbf{6}$ \\
\hline Czujnik 4, kierunek pionowy** & $\mathbf{7}$ & 1 & 3 & 1 & 3 \\
\hline \multicolumn{2}{|l|}{ Oznaczenia nadwozia } & $\boldsymbol{A}$ & $\boldsymbol{B} / \boldsymbol{A}$ & $\boldsymbol{C} / \boldsymbol{B}$ & $\boldsymbol{D} / \boldsymbol{C}$ & $\boldsymbol{D}$ \\
\hline Czujnik 5, kierunek pionowy & 9 & $\mathbf{1 2}$ & 0 & 1 & 1 \\
\hline Czujnik 6, kierunek poprzeczny* & $\mathbf{1 5}$ & 3 & 0 & 3 & - \\
\hline
\end{tabular}

Źródło: opracowanie własne na podstawie [10]

Tabela 4.

Liczby przekroczeń dopuszczalnych poziomów Wartości średniokwadratowej wg czujników pomiarowych o wskazanych położeniach na wózkach i nadwoziach pojazdu szynowego w dniu 23 stycznia 2012 r. ( ${ }^{*}$ E-Ø; ** Eczujnik 6, kierunek pionowy)

\begin{tabular}{|l|c|c|c|c|c|}
\hline \multicolumn{1}{|c|}{ Oznaczenie wózka } & $\boldsymbol{A}$ & $\boldsymbol{B}$ & $\boldsymbol{C}$ & $\boldsymbol{D}$ & $\boldsymbol{E}$ \\
\hline Czujnik 1, kierunek poprzeczny* & 0 & 0 & 0 & 0 & - \\
\hline Czujnik 2, kierunek poprzeczny* & 0 & 0 & 0 & 0 & - \\
\hline Czujnik 3, kierunek pionowy & 0 & 0 & 1 & 1 & 1 \\
\hline Czujnik 4, kierunek pionowy** & 0 & 0 & 1 & 0 & 1 \\
\hline \multicolumn{1}{|c|}{ Oznaczenia nadwozia } & $\boldsymbol{A}$ & $\boldsymbol{B} / \boldsymbol{A}$ & $\boldsymbol{C} / \boldsymbol{B}$ & $\boldsymbol{D} / \boldsymbol{C}$ & $\boldsymbol{D}$ \\
\hline Czujnik 5, kierunek pionowy & 0 & 0 & 0 & 0 & 0 \\
\hline Czujnik 6, kierunek poprzeczny* & 0 & 0 & 0 & 1 & - \\
\hline
\end{tabular}

Źródło: opracowanie własne na podstawie [10]

\section{Wartość średniokwadratowa (RMS)}

W przypadku analizowania dopuszczalnych poziomów Wartości średniokwadratowej wyniki zawarto w tabeli 3. Najwięcej przekroczeń tego parametru, w ujęciu bezwzględnym, dotyczy wózków $A, E$ i nadwozia $A$ (tabela 3.). Przy czym, ze względu na odmienną konfigurację czujników, w przypadku wózka $E$ brak jest danych dotyczących przekroczeń w przypadku czujników 1, 2 umiejscowionych na wózku, a także czujnika 6 umiejscowionego na nadwoziu. Gdyby danymi dysponowano, niewykluczone, że to wózek $E$ byłby „obciążony” największą liczbą przekroczeń dopuszczalnych wartości parametru statystycznego, co dotyczy także Amplitudy. W tabeli pogrubiono wartości uznane za najwyższe.

Szczegółowy wykaz pakietów (ze zmienionymi na potrzeby artykułu nazwami pakietów - pakietom $\mathrm{z}$ nadano numery kolejne), w odniesieniu do tabeli 4 ., zawierających przekroczenia Wartości średniokwadratowej w dniu 23 stycznia 2012 r., z podziałem na elementy pojazdu szynowego:

- $\quad$ wózek C: Pakiet nr 1: $R M S_{0 V 1 B}=8,47$ przy progowej wartości $R M S_{g r}=7,00$; 
Pakiet $n r$ 2: $R M S_{2 V I B}=10,66$ przy progowej wartości $R M S_{g r}=7,00$;

Obydwa ww. przekroczenia zostały zarejestrowane w systemie na odcinku trasy zapoczątkowanym w miejscu oznaczonym na rys. 4. symbolem białego rombu. Prawdopodobnie do przekroczeń doszło w miejscu przejazdu kolejowego krzyżującego linię kolejową nr 3 z drogą nr 92 (rys. 4., symbol białej strzałki).

- $\quad$ nadwozie $D / C$ : Pakiet $n r 3: R M S_{9 V I B}=0,51$ przy progowej wartości $R M S_{g r}=0,50$;

Przekroczenie zostało zarejestrowane w systemie na odcinku trasy zapoczątkowanym $\mathrm{w}$ miejscu oznaczonym na rys. 7. symbolem białego rombu. Prawdopodobnie do przekroczeń doszło w miejscu przejazdu kolejowego krzyżującego linię kolejową $\mathrm{nr} 3 \mathrm{z}$ drogą $\mathrm{w}$ okolicy miejscowości Barłogi (rys. 7., symbol białej strzałki).

- $\quad$ wózek D: Pakiet $n r$ 4: $R M S_{\text {OVIB }}=9,13$ przyprogowej wartości $R M S_{g r}=7,00$;

Przekroczenie zostało zarejestrowane w systemie na odcinku trasy zapoczątkowanym w miejscu oznaczonym na rys. 5. symbolem białego rombu. Prawdopodobnie do przekroczenia doszło w miejscu przejazdu kolejowego krzyżującego linię kolejową $\mathrm{nr} 3 \mathrm{z}$ drogą nr 92 (rys. 5., symbol białej strzałki).

- wózek E: Pakiet $n r$ 5: $R M S_{\text {OVIB }}=8,31$ przyprogowej wartości $R M S_{g r}=7,00$;

Pakiet $n$ r 6: $R M S_{I V I B}=7,46$ przyprogowej wartości $R M S_{g r}=7,00$.

Obydwa ww. przekroczenia zostały zarejestrowane w systemie na odcinku trasy zapoczątkowanym w miejscu oznaczonym na rys. 6. symbolem białego rombu. Prawdopodobnie do przekroczeń doszło w miejscu przejazdu kolejowego krzyżującego linię kolejową $\mathrm{nr} 3 \mathrm{z}$ drogą w miejscowości Milin (rys. 6., symbol strzałki).

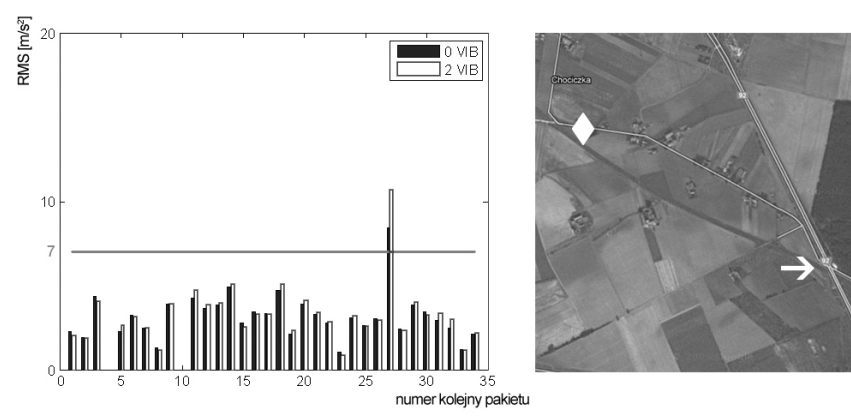

Rys. 4. Figura po lewej: wykres dla $R M S$ obliczonych $\mathrm{z}$ rozróżnieniem na poszczególne pakiety danych - analiza dla dnia 23 stycznia 2012 r., dla wózka $C$ - przyspieszenie pionowe na wózku wg wskazań położenia czujników pomiarowych: czujnik 3, czujnik 4; figura po prawej: miejsce rejestracji pakietu $\mathrm{z}$ przekroczeniem wartości progowej $R M S$ w okolicy miejscowości Chociczka
Źródło: analizator napisany w oprogramowaniu MATLAB, autor: Melnik R.; Google maps
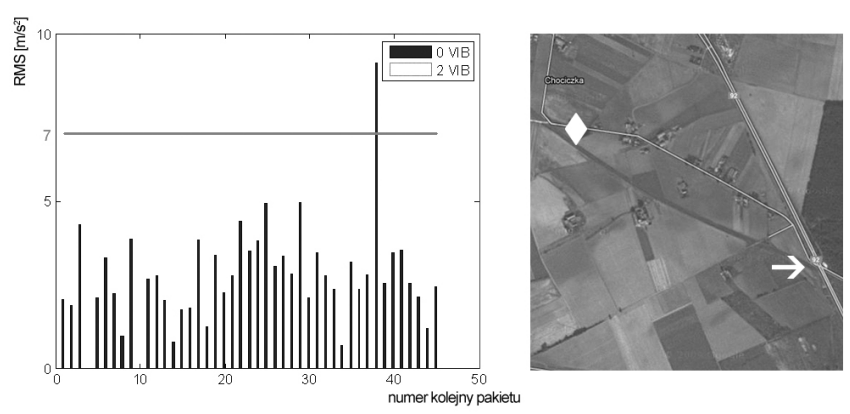

Rys. 5. Figura po lewej: wykres dla $R M S$ obliczonych z rozróżnieniem na poszczególne pakiety danych - analiza dla dnia 23 stycznia 2012 r., dla wózka $D$ - przyspieszenie pionowe na wózku wg wskazań położenia czujnika 3; figura po prawej: miejsce rejestracji pakietu z przekroczeniem wartości progowej $R M S$ w okolicy miejscowości Chociczka

Źródło: analizator napisany w oprogramowaniu MATLAB, autor: Melnik R.; Google maps

Jedyny pakiet, w odniesieniu do tabeli 5., zawierający przekroczenie Wartości średniokwadratowej w dniu 25 stycznia 2012 r., zarejestrowany został na:

- wózku D:

Pakiet $n r$ 7: $R M S_{0 V I B}=7,15$ przy progowej wartości $R M S_{g r}=7,00$.

Przekroczenie zarejestrowano w miejscu na trasie oznaczonym na rys. 8 . symbolem białego rombu. Prawdopodobnie do przekroczeń doszło w miejscu złączy szyn w okolicy stacji Koło (oznaczonego na rys. 8. symbolem białej strzałki).

W dniu 26 stycznia 2012 r. nie zarejestrowano przekroczeń Wartości średniokwadratowych.
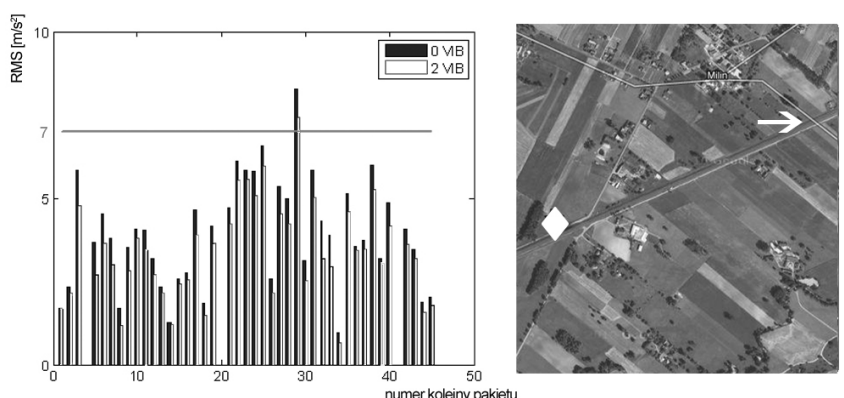

Rys. 6. Figura po lewej: wykres dla $R M S$ obliczonych z rozróżnieniem na poszczególne pakiety danych - analiza dla dnia 23 stycznia 2012 r., dla wózka $E$ - przyspieszenie pionowe na wózku wg wskazań położenia czujników pomiarowych: czujnik 3 , czujnik 4; figura po prawej: miejsce rejestracji pakietu z przekroczeniem wartości progowej $R M S$ w okolicy miejscowości Milin

Źródło: analizator napisany w oprogramowaniu MATLAB, autor: Melnik R.; Google maps

\section{Wspótczynnik kurtozy}

W przypadku rozpatrywania współczynnika kurtozy za rozkład odniesienia przyjmuje się rozkład normalny. Dla tego rozkładu wartość współczynnika 
kurtozy wynosi 3. Wówczas, gdy rozproszenie populacji (w rozpatrywanej analizie: analizowanych danych skupionych w obrębie jednego pakietu) jest większe niż w przypadku rozkładu normalnego tj. gdy współczynnik kurtozy jest $\mathrm{K}<3$, histogram dla tej populacji jest wyższy i bardziej rozłożysty, [11]. Wówczas zwyczajowo mówi się, że analizowane dane mają rozkład typu platokurtycznego. W przeciwnym przypadku mówi się, że analizowane dane przyjmują rozkład typu leptokurtycznego.

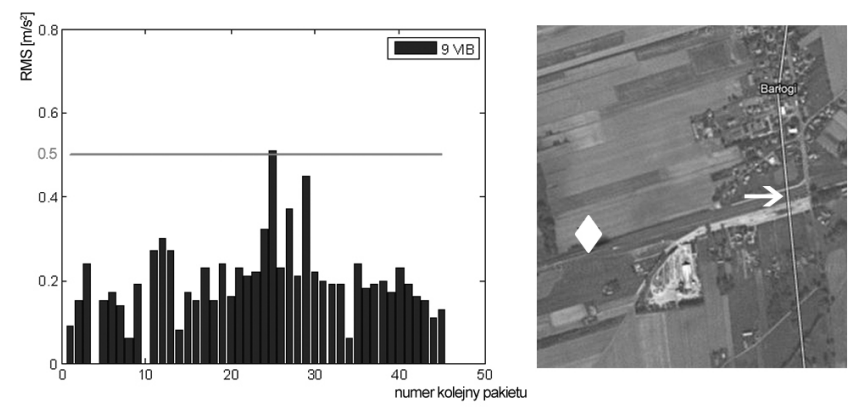

Rys. 7. Figura po lewej: wykres dla $R M S$ obliczonych z rozróżnieniem na poszczególne pakiety danych - analiza dla dnia 23 stycznia 2012 r., dla nadwozia $D / C$ - przyspieszenie pionowe na nadwoziu wg wskazań położenia czujnika 6; figura po prawej: miejsce rejestracji pakietu z przekroczeniem wartości progowej $R M S$ w okolicy miejscowości Barłogi

Źródło: analizator napisany w oprogramowaniu $M A T L A B$, autor: Melnik R.; Google maps
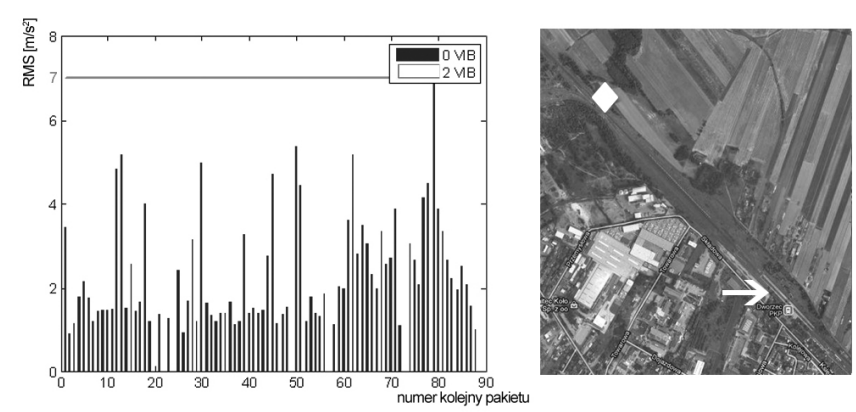

Rys. 8. Figura po lewej: wykres dla $R M S$ obliczonych z rozróżnieniem na poszczególne pakiety danych - analiza dla dnia 25 stycznia 2012 r., dla wózka $E$ - przyspieszenie pionowe na wózku wg wskazań położenia czujników pomiarowych: czujnik 3 , czujnik 4; figura po prawej: miejsce rejestracji pakietu z przekroczeniem wartości progowej $R M S$ w okolicy miejscowości Koło

[uwaga: wartość większa od progowej znajduje się za legenda]

Źródło: analizator napisany w oprogramowaniu MATLAB, autor: Melnik R.; Google maps
Przyjmuje się, że dla współczynnika kurtozy o wartości z przedziału od 0 do 6 występuje koncentracja danych wokół wartości średniej populacji.

Podobnie jak w przypadku pozostałych wskaźników diagnostycznych, także wartości Wspótczynnika kurtozy powinny podlegać porównywaniu z odpowiadającymi mu wartościami dopuszczalnymi. Wobec porównywania kolejnych wartości współczynnika kurtozy z wartością dopuszczalną tejże należałoby poczynić założenie o identyczności rozkładów danych analizowanych $\mathrm{w}$ jednym pakiecie $\mathrm{z}$ danymi analizowanymi $\mathrm{w}$ pozostałych pakietach. W celu weryfikacji założenia należałoby w pierwszej kolejności przeprowadzić test zgodności KołmogorovaSmirnova (lub też test Kruskala-Wallisa, który jest rangowym testem statystycznym porównującym rozkłady zmiennych dla większej niż 2 liczby populacji analizowanych danych). Test służy weryfikowaniu hipotezy o identyczności rozkładów badanej cechy dla dwóch populacji (czyli danych w obrębie 2 pakietów). Nie jest to dobre rozwiązanie, bowiem gdyby badanie hipotezy dało wynik negatywny, skutkowałoby to wykluczeniem rozpatrywanego pakietu $\mathrm{z}$ dalszych analiz, a w konsekwencji z porównywania wartości diagnostycznych $\mathrm{z}$ ich dopuszczalnymi odpowiednikami. Metoda byłaby czasochłonna i nie dawałaby satysfakcjonującego rezultatu.

$\mathrm{Z}$ analizy wynika jednak wniosek przeciwny do przyjętego założenia: rozkłady analizowanych danych $w$ obrębie danego pakietu są odmienne od rozkładów danych w przypadku innych pakietów.

Wspótczynnik kurtozy w „czystej” postaci jest w związku z powyższym niemiarodajnym wskaźnikiem diagnostycznym, jest to klasyczna miara koncentracji populacji.

W ramach analizy podjęto próbę powiązania Wartości średniokwadratowych $\mathrm{z}$ wartościami Wspótczynnika kurtozy. Porównywano dane w przypadkach, gdy wystapiło przekroczenie wartości dopuszczalnej dla Wartości średniokwadratowej z wartością Wspótczynnika kurtozy obliczoną dla tego samego pakietu. Rezultatem jest brak jakiejkolwiek zależności. Można jedynie stwierdzić, że Wspótczynnik kurtozy o wartości maksymalnej wystapił $\mathrm{w}$ przypadku innego pakietu z przejazdu pojazdu szynowego na tej

Liczby przekroczeń dopuszczalnych poziomów Wartości średniokwadratowej wg czujników pomiarowych o wskazanych położeniach na wózkach i nadwoziach pojazdu szynowego w dniu 25 stycznia 2012 r. (* E-Ø; ** Eczujnik 6, kierunek pionowy)

\begin{tabular}{|l|r|r|r|r|r|}
\hline \multicolumn{1}{|c|}{ Oznaczenie wózka } & $\boldsymbol{A}$ & \multicolumn{1}{c|}{$\boldsymbol{B}$} & $\boldsymbol{C}$ & \multicolumn{1}{c|}{$\boldsymbol{D}$} & $\boldsymbol{E}$ \\
\hline Czujnik 1, kierunek poprzeczny* & - & 0 & 0 & 0 & - \\
\hline Czujnik 2, kierunek poprzeczny* & - & 0 & 0 & 0 & - \\
\hline Czujnik 3, kierunek pionowy & - & 0 & 0 & 1 & 0 \\
\hline Czujnik 4, kierunek pionowy** & - & 0 & 0 & 0 & 0 \\
\hline \multicolumn{1}{|c|}{ Oznaczenia nadwozia } & $\boldsymbol{A}$ & $\boldsymbol{B} / \boldsymbol{A}$ & $\boldsymbol{C} / \boldsymbol{B}$ & $\boldsymbol{D} / \boldsymbol{C}$ & $\boldsymbol{D}$ \\
\hline Czujnik 5, kierunek pionowy & - & 0 & 0 & 0 & 0 \\
\hline Czujnik 6, kierunek poprzeczny* & - & 0 & 0 & 0 & - \\
\hline
\end{tabular}


samej trasie i tego samego dnia, a Wartość średniokwadratowa nie uległa przekroczeniu odpowiadającej jej wartości dopuszczalnej (kolumna $6 \mathrm{w}$ tabeli 6.). Przypadek, gdy wartość maksymalna Współczynnika kurtozy występuje wówczas, gdy wartość dopuszczalna Wartości średniokwadratowej została przekroczona, został w tabeli 6. „wyróżniony” ( $\square$ ). Pakiet, w przypadku którego doszło do tej sytuacji, został jednak zarejestrowany na innej trasie niż rozpatrywana w artykule (Warszawa-Kraków).

\section{Wnioski}

Dokonana analiza wywarła przekonanie o niemożliwości traktowania każdego ze wskaźników diagnostycznych osobno. Wskaźniki diagnostyczne powinny być traktowane zespołowo. Do opracowania algorytmu postępowania w takim przypadku niezbędne są dodatkowe analizy obejmujące szersze spektrum wyników niż tylko dla wybranej trasy przejazdu pojazdu szynowego. Zanim jednak przygotowany zostanie algorytm prowadzący do zespolonego spojrzenia na wszystkie wskaźniki diagnostyczne, musi zostać dokonana ocena ważkości i ważności poszczególnych wskaźników diagnostycznych. Przy tym jednocześnie musi zostać dokonane określenie dopuszczalnych poziomów innych, w stosunku do podanych w treści artykułu, wskaźników diagnostycznych tj. współczynnika kurtozy, rozstępu międzykwartylowego. Wspomniane prace (w toku realizacji) pozwolą na permanentne i jednoznaczne określenie użytecznych wskaźników diagnostycznych.

Jak wskazano w podrozdziale na temat Wspótczynnika kurtozy jednoczesna analiza wartości średniokwadratowej i współczynnika kurtozy nie daje satysfakcjonujących wyników. Przekroczenia dopuszczalnych wartości średniokwadratowych występują sporadycznie i najczęściej podejrzenie ich wystąpienia ma związek z przejazdem pojazdu szynowego przez rozjazd kolejowy czy przejazd kolejowy. Zatem ów wskaźnik diagnostyczny jako taki nie może podlegać ocenie w sposób niezależny od innych wskaźników diagnostycznych. Warto rozważyć zespolone spojrzenie na pary wskaźników: Amplituda i Współczynnik kurtozy czy też Rozstęp międzykwartylny i Współczynnik kurtozy przy jednoczesnym braniu pod uwage częstości przekroczenia ich wartości dopuszczalnych w przypadku sąsiadujących ze sobą pakietów czyli ich występowanie w ujęciu drogi lub upływającego czasu przejazdu pojazdu szynowego.

W celu jednoznacznego określenia miejsc występowania przekroczeń na mapie należałoby powiązać otrzymywane współrzędne geograficzne (współrzędne generowane w miejscu, z którego następuje przesłanie pakietów zebranych przez CJAD) i odległość podaną $\mathrm{W}$ pakiecie $\mathrm{z}$ kilometrażem kolejowym. W bazie danych musiałaby istnieć tabela danych zawierająca informacje nt. numeru linii kolejowej, słupków kilometrażu na niej występujących wraz z przyporządkowaniem ich współrzędnych geograficznych. Wówczas można by dla zarejestrowanego w pakiecie przekroczenia, wyznaczyć obszar czy miejsce wystapienia przekroczenia na torze $\mathrm{z}$ dokładnością do odległości między słupkami kilometrażu.

$\mathrm{W}$ analizie zasadniczo pominięto wózek $E$ przy porównywaniu go $\mathrm{z}$ innymi wózkami ze względu na brak przyporządkowania czujników wszystkim lokalizacjom przewidzianym w projekcie. Była to sprawa umowna w trakcie eksploatacji nadzorowanej pojazdu szynowego, na którym zainstalowano system. Sytuacja w bieżącej eksploatacji systemu byłaby oczywiście odmienna - montowano by czujniki konsekwentnie, w tych samych miejscach.

Kwestię sporną stanowi nierównomierny przesył pakietów. Trwają prace nad wyjaśnieniem problemu.

\section{Lit er a t u r a}

[1.] Buda A., Jarynowski A., Life-time of correlations and its applications vol.1, Wydawnictwo Niezalezne: 5-21, 2010

[2.] Cohen J., Satistical power analysis for the behavioral sciences (2nd ed.), Lawrence Erlbaum Associates, Inc., New Jersey, USA, 1988

[3.] SMPK - Konfiguracja system testowego na pojeździe ED74, MONIT - Testowanie systemu w warunkach eksploatacyjnych, EC Systems, Kraków, listopad 2011 r.

[4.] EN 14363: 2005. Railway applications - Testing for the acceptance of running characteristics of railway vehicles - Testing of running behaviour and stationary tests

[5.] PN-EN 14363. Badania własności dynamicznych pojazdów szynowych przed dopuszczeniem pojazdu do ruchu. Badania własności biegowych i próby stacjonarne

Wartość średniokwadratowa a współczynnik kurtozy - porównanie wskaźników diagnostycznych Tabela 6.

\begin{tabular}{|c|c|c|c|c|c|}
\hline $\begin{array}{c}\text { Identyfikator } \\
\text { pakietu }\end{array}$ & $\begin{array}{c}\text { Kanal } \\
\text { (wózek) }\end{array}$ & $\begin{array}{l}\text { Wartość śred- } \\
\text { niokwadrato- } \\
\text { wa }\left(\text { RMS }_{\text {dop }}\right)\end{array}$ & $\begin{array}{l}\text { Współczynnik } \\
\text { kurtozy }\end{array}$ & Typ rozkładu & Uwagi \\
\hline \multicolumn{6}{|c|}{ Rozpatrywana trasa: Warszawa-Poznań } \\
\hline $20120123 \quad 194328$ & 7VIB (E) & $8,31(7)$ & 4,20 & Leptokurtyczny & $\mathrm{K}(18: 04: 14)=20,68 ; \mathrm{RMS}=1,71$ \\
\hline $20120123 \_194328$ & 8VIB (E) & $7,46(7)$ & 5,77 & Leptokurtyczny & $\mathrm{K}(20: 37: 20)=37,07 ; \mathrm{RMS}=3,23$ \\
\hline $20120123 \quad 202229$ & 0VIB (C) & $8,47(7)$ & 3,71 & Leptokurtyczny & $\mathrm{K}(18: 25: 32)=58,34 ; \mathrm{RMS}=3,89$ \\
\hline $20120123 \quad 202229$ & 2VIB (C) & $10,66(7)$ & 3,47 & Leptokurtyczny & $\mathrm{K}(18: 25: 32)=61,22 ; \mathrm{RMS}=3,90$ \\
\hline $20120123 \_193050$ & 9VIB (D/C) & $0,51(0,5)$ & 5,40 & Leptokurtyczny & $\mathrm{K}(18: 04: 14)=14,23 ; \mathrm{RMS}=0,09$ \\
\hline $20120123 \quad 202229$ & 0VIB (D) & $9,13(7)$ & 4,29 & Leptokurtyczny & $\mathrm{K}(19: 01: 29)=73,36 ; \mathrm{RMS}=3,86$ \\
\hline $20120125 \_193632$ & 0VIB (D) & $7,15(7)$ & 82,45 & Leptokurtyczny & $\mathrm{K}(19: 50: 37)=96,94 ; \mathrm{RMS}=3,34$ \\
\hline \multicolumn{6}{|c|}{ Rozpatrywana trasa: Warszawa-Kraków } \\
\hline 20120131064934 & 9VIB (A/A) & $0,8(0,5)$ & 33,99 & Leptokurtyczny & \\
\hline
\end{tabular}


[6] UIC 518: 2009, 4th edition, Testing and approval of railway vehicles from the point of view of their dynamic behaviour - Safety - Track fatigue; Ride quality

[7] Analiza drgań elementów i zespołów pojazdów szynowych w oparciu o wyniki badań eksperymentalnych, EZT przyspieszenia, Monit, IK (dawniej CNTK), Warszawa, 2009

[8] Chudzikiewicz A., Sowiński B., Droździel J.: Zadanie 6. Testowanie prototypu systemu $w$ warunkach eksploatacyjnych, Temat 6.2 Opracowanie planu i procedury badań eksploatacyjnych prototypu systemu monitorowania pojazd szynowy - tor, raport MONIT, 2012
[9] Prospekt reklamowy: http://pesa.pl/pl/Oferta/Elektryczne zespoly_trakcyjne/ED74_Bydgostia

[10] Chudzikiewicz A., Sowiński B., Droździel J., Opala M. Kostrzewski M., Michalski K., Melnik R.: Zadanie 6. Testowanie prototypu systemu $w$ warunkach eksploatacyjnych, Temat 6.4 Analiza wyników testów eksploatacyjnych, raport MONIT, 2012

[11] Moszczyński L., Interpretacja współczynnika kurtozy w analizie danych, Przeglad Elektrotechniczny, R. 79, nr 9(1), s.558--560, Wydawnictwo SIGMA-NOT, 2003 